Diklabio: Jurnal Pendidikan dan Pembelajaran Biologi, 5 (2), 169-177 (2021)

Diklabio: Jurnal Pendidikan dan Pembelajaran Biologi

Journal homepage: https://ejournal.unib.ac.id/index.php/jppb

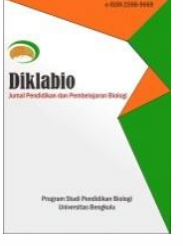

\title{
Pengembangan Modul Pembuatan Ecobrick Sampah Plastik Sebagai Sarana Pengembangan Diri Berbasis Ecopreneurship Di SMA Kelas X
}

\author{
Akbar Handoko $^{1 *}$, Bambang Sri Anggoro², M.Marzuki ${ }^{3}$, Putri Nuragustin ${ }^{4}$ \\ ${ }^{1,4}$ Program Studi S-1 Pendidikan Biologi, Fakultas Tarbiyah dan Keguruan, Universitas Islam \\ Negeri Raden Intan Lampung, Indonesia \\ ${ }^{2}$ Program Studi S-1 Pendidikan Matematika, Fakultas Tarbiyah dan Keguruan, Universitas Islam \\ Negeri Raden Intan Lampung, Indonesia \\ 3 Program Studi S-1 Pendidikan Biologi, Fakultas Matematika dan Ilmu Pengetahuan Alam, \\ Universitas Hamzanwadi, Indonesia
}

*Email: putrilpg116@gmail.com

\begin{tabular}{|c|c|}
\hline Info Artikel & Abstrak \\
\hline $\begin{array}{l}\text { Diterima: } 31 \text { Mei } 2021 \\
\text { Direvisi: } 24 \text { Oktober } 2021 \\
\text { Diterima } \\
\text { untuk diterbitkan: } 31 \text { Oktober } \\
2021\end{array}$ & $\begin{array}{l}\text { Ecopreneurship adalah istilah untuk mewakili proses atau } \\
\text { prinsip kewirausahaan guna mengatasi masalah lingkungan. } \\
\text { Tujuan penelitian (1) mengetahui kelayakan modul pembuatan } \\
\text { Ecobrick sebagai sarana pengembangan diri berbasis } \\
\text { Ecopreneurship di SMA kelas X. (2) mengetahui tanggapan }\end{array}$ \\
\hline $\begin{array}{l}\text { Keywords: } \\
\text { Modul pembuatan Ecobrick, } \\
\text { Ecopreneurship }\end{array}$ & $\begin{array}{l}\text { peserta didik dan guru mengenai modul pembuatan Ecobrick } \\
\text { sebagai sarana pengembangan diri berbasis Ecopreneurship di } \\
\text { SMA kelas X. Jenis penelitian adalah Research and } \\
\text { Development (R\&D) yang dikembangkan oleh Robert Maribe } \\
\text { Branch menggunakan model ADDIE (analysis, design, } \\
\text { development, implementation, \& evaluation) yang dilakukan } \\
\text { secara menyeluruh tanpa adanya batasan. Uji coba penelitian } \\
\text { dengan dua kelompok yakni kelompok kecil (30 peserta didik) } \\
\text { dan kelompok besar (64 peserta didik). Hasil penelitian adalah } \\
\text { modul pembuatan Ecobrick. Kualitas dari modul pembuatan } \\
\text { Ecobrick sebagai berikut: (1) ahli media diperoleh persentase } \\
82,29 \% \text { dengan kriteria "sangat layak", (2) ahli bahasa } \\
\text { diperoleh persentase } 81,81 \% \text { dengan kriteria "sangat layak", } \\
\text { (3) ahli materi diperoleh persentase } 97,72 \% \text { dengan kriteria } \\
\text { "sangat layak". Hasil tanggapan pendidik biologi diperoleh } \\
\text { persentase 83,33 \% dengan kriteria "sangat layak". Hasil } \\
\text { penilaian pendidik kewirausahaan diperoleh persentase 79,16 } \\
\text { dengan kriteria "layak". Hasil tanggapan peserta didik } \\
\text { diperoleh } 88,47 \% \text { dengan kriteria "sangat layak". Dari hasil } \\
\text { penilaian modul dapat dikatakan sangat layak untuk digunakan. }\end{array}$ \\
\hline
\end{tabular}




\section{PENDAHULUAN}

Perkembangan industri yang kian meningkat menghasilkan berbagai barang-barang yang bermanfaat bagi aktivitas manusia, semisal plastik. Plastik memiliki sifat kuat, plastik baru bisa diuraikan dalam waktu 80 sampai 300 tahun (Purnama \& Yuriandala, 2010). Sifat kuat yang dimiliki oleh plastik yang membuat plastik sulit untuk terurai.

Penggunaan bahan plastik (Fatimura, 2020) yang senantiasa meningkat setiap hari menjadi penyebab penumpukan plastik. Di tambah pada awal Maret 2019, Indonesia mulai mengalami krisis kesehatan akibat penyakit yang disebabkan oleh virus Corona atau lebih dikenal dengan Covid-19. Akibat pandemi Covid-19 (Purba, 2021) menyebabkan peningkatan timbunan sampah plastik dan sampah medis. Lembaga Ilmu Pengetahuan Indonesia menyatakan bahwasanya sampah plastik domestik meningkat dimulai dari 1-5 menjadi 5-10 gram per hari per individu karena pandemi Covid-19. Selain itu, Kementerian Lingkungan Hidup dan Kehutanan mencatat kenaikan produksi limbah medis saat ini sebanyak 290 ton limbah medis per hari pada tahun 2020 (Suryani, 2020).

Pembuangan sampah plastik (Pratami, 2021) secara sembarangan ini menyebabkan kerusakan lingkungan akibat sampah plastik yang sulit untuk terurai. Dampak negatif dari limbah plastik tidak dapat dipungkiri, tetapi melalui cara/ metode pengelolaan yang tepat limbah plastik bisa dirubah menjadi sesuatu yang berharga dan bernilai. Metode pengolahan sampah plastik melalui 3 cara, yakni reduce adalah pembatasan timbulan sampah, reuse adalah pemanfaatan kembali sampah, dan recycle adalah pendauran ulang sampah (Gunawan, 2018). Dengan demikian, sampah plastik dapat dimanfaatkan menjadi barang kreasi yang bernilai ekonomis lebih tinggi (Asri et al., 2018).

Metode yang dapat dilakukan untuk pengeloaan sampah plastik yakni dengan metode Ecobrick (Ansali \& Dewi, 2019). Ecobrick merupakan teknik pengelolaan sampah plastik yang terbuat dari botol-botol plastik bekas yang di dalamnya telah diisi berbagai sampah plastik hingga terisi penuh dan padat (Afriza, Edi Fitriana, 2018).

Pembuatan Ecobrick dengan memanfaatkan sampah plastik ini dapat menjadi sarana pengembangan diri. Pengembangan diri membutuhkan sarana yang dapat menunjang keberhasilan dalam mengembangkan diri. Sarana yang dibutuhkan yakni suatu projek atau praktek lapangan yang dapat menjadi penunjang dalam mengembangkan diri. Mata pelajaran yang menjadi sasaran dalam pengembangan diri ini adalah materi pencemaran lingkungan. Melalui materi ini, siswa diharapkan akan mampu dan mengetahui cara menjaga lingkungan dengan baik melalui media pengolahan sampah plastik (Ecobrick) dan juga mata pelajaran pendidikan kewirausahaan. Peserta didik akan belajar dua hal sekaligus, selain belajar cara membuat Ecobrick, peserta didik juga belajar cara mencintai lingkungan.

Jiwa Ecopreneurship juga perlu dikembangkan dikalangan peserta didik. Ecopreneurship sendiri merupakan jiwa kewirausaan berbasis lingkungan (Anih, 2015). Pendidikan kewirausahaan atau entrepreneurship dapat diartikan sebagai pendidikan bagi calon pengusaha agar memiliki keberanian, kemandirian, serta keterampilan sehingga meminimalkan kegagalan dalam usaha (Adinugraha, 2017). Pendidikan kewirausahaan menjadi salah satu mata pelajaran yang penting saat ini. Melalui pendidikan kewirusahaan (PKWU), peserta didik diajak untuk belajar berkarya.

Pendidikan kewirausahaan (PKWU) di sekolah umumnya membuat kerajinan tangan yang hanya dapat dikerjakan di lingkungan sekolah. Kerajinan tangan ini memerlukan alat dan bahan yang kadang sulit didapat, mahal, dan dibutuhkan dalam jumlah banyak menyesuaikan jumlah peserta didik. Banyaknya kendala ini, mengharuskan guru dapat membuat inovasi-inovasi yang dapat menunjang proses pembelajaran ini. Karena hal ini, peneliti melakukan pengembangan media pembelajaran yang dapat membantu guru dalam proses pembelajaran. Dengan adanya modul yang berisi materi-materi, lembar kerja yang berisi langkah-langkah, alat dan bahan diharapkan dapat memudahkan peserta didik dalam belajar. Pembelajaran juga dapat dikerjakan di rumah masingmasing dengan adanya modul ini.

Modul mejadi sarana yang dapat digunakan bagi peserta didik sebagai salah satu media 
pembelajaran. Modul merupakan bentuk upaya yang berfungsi untuk meningkatkan pengetahuan peserta didik dalam proses pembelajaran yang bersifat aktif dengan mengutamakan kepada peserta didik (Sari, Angreni, \& Fortuna, 2019). Modul adalah alat bantu (Hamid \& Alberida, 2021) yang sudah banyak digunakan dalam kegiatan pembelajaran di sekolah. Modul pembuatan Ecobrick menjadi salah satu modul yang dapat digunakan di sekolah.

\section{METODE}

Peneliti menggunakan jenis penelitian metode pengembangan $\mathrm{RnD}$ (Research and Development). Motode pengembangan ini dilakukan guna mengembangan suatu produk baru yang akan menyempurnakan produk yang telah ada dan dapat dipertanggungjawabkan. Pengembangan model ini mengikuti model yang dikembangkan oleh Robert Maribe Branch. Adapun ruang lingkupnya adalah buku panduan (Afandi, 2010).

Model penelitian yang digunakan adalah model penelitian dan pengembangan ADDIE (Analysis, Design, Development, Implementation, Evaluation) (Pudjawan, 2015). Model ADDIE adalah sebuah konsep pengembangan produk (Handoko, Sajidan, \& Maridi, 2016) yang merupakan suatu model yang di dalamnya merepresentasikan tahapan-tahapan secara sistematika (tertata) dan sistemis dalam penggunaan bertujuan untuk tercapainya hasil yang diinginkan (Wulandari, 2018).

\section{Analysis}

Langkah analisis terdiri atas dua tahap, yaitu analisis kinerja (performance analysis) dan analisis kebutuhan (need analysis).

\section{Design}

Langkah kedua yang dilakukan yaitu merancang (desain), sebelum pembuatan media pembelajaran diperlukan adanya rancangan (desain) suatu media. Rancangan ini nantinya akan dikembangkan menjadi media pembelajaran yang siap digunakan. Pada media pembelajaran ini langkah merancang media dilihat dari segi desain, segi materi, dan segi bahasa. Kemudian baru ke tahap berikutnya dengan mengembangkan sebuah media pembelajaran.

\section{Development}

Langkah ketiga ini yaitu mengembangkan media pembelajaran. Adapun tahap-tahap yang dilakukan peneliti dalam mengembangkan modul pembuatan Ecobrick, adalah: a) melakukan pembuatan media pembelajaran, yakni buku panduan pembuatan Ecobrick. Pembuatan modul dilihat dari segi desain, segi materi, dan segi bahasa, b) mereview media pembelajaran yang dikembangkan dengan memvalidasikan media pembelajaran oleh tim ahli media, ahli materi, dan ahli bahasa, dan c) memperbaiki media pembelajaran sesuai dengan saran dan masukan dari tim ahli media, ahli materi, dan ahli bahasa (Wulandari, 2018).

\section{Implementation}

Langkah ini yaitu melakukan implementasi media pembelajaran dalam proses pembelajaran di sekolah. Dengan mempraktekkan langkah-langkah dalam membuat Ecobrick yang tertera di dalam modul bersama peserta didik kelas X.

\section{Evaluation}

Berdasarkan tahapan implementasi, modul pembuatan Ecobrick perlu dilakukan evaluasi. Pada tahap evaluasi, dilakukan revisi akhir terhadap produk yang dikembangkan berdasarkan saran dan masukan peserta didik yang diberikan selama tahap implementasi.

Instrumen yang digunakan untuk pengumpulan data pada penelitian ini berupa angket. Data yang diperoleh digunakan untuk mengetahui kelayakan produk yang dikembangkan. Untuk mengetahui apakah modul pembuatan Ecobrick dan instrumen yang telah dirancang valid atau tidak. Angket tanggapan bersifat kuantitatif data dapat diolah secara penyajian persentase dengan menggunakan skala Likert sebagai skala pengukuran (Riduwan, 2014). 


\section{Tabel 1}

Skor Penilaian Terhadap Pilihan Jawaban

\begin{tabular}{lll}
\hline No & Analisis Kuantitatif & Skor \\
\hline 1 & Sangat baik & 5 \\
\hline 2 & Baik & 4 \\
\hline 3 & Cukup & 3 \\
\hline 4 & Kurang Baik & 2 \\
\hline 5 & Sangat Kurang & 1 \\
\hline
\end{tabular}

Hasil dari skor penilaian tersebut kemudian dicari rata-ratanya dari sejumlah subjek sampel uji coba dan dikonversikan ke pernyataan penilaian untuk menentukan kualitas dan tingkat kemanfaatan produk yang dihasilkan berdasarkan pendapat pengguna. Pengonversian skor menjadi persyaratan penilaian ini dapat dilihat dalam Tabel 2 (Arikunto, 2013).

\section{Tabel 2}

Skala Kelayakan Media Pembelajaran

\begin{tabular}{ll}
\hline Skor Presentasi & Interpretasi \\
\hline $81 \%-100 \%$ & Sangat Layak \\
\hline $61 \%-80 \%$ & Layak \\
\hline $41 \%-60 \%$ & Cukup Layak \\
\hline $21 \%-40 \%$ & Kurang Layak \\
\hline $0 \%-20 \%$ & Sangat Kurang Layak \\
\hline
\end{tabular}

Tingkat pengukuran skala dalam penelitian ini menggunakan interval. Data interval dapat dianalisis dengan menghitung rata-rata jawaban berdasarkan skoring setiap jawaban dari responden.

Jumlah Jawaban $=\frac{\text { Jumlah skor yang diperoleh }}{\text { Jumlah skor tertinggi }} \times 100$

Angket yang digunakan sebagai lembar penilaian terdiri atas angket validasi ahli materi, ahli bahasa, ahli media, angket guru, dan peserta didik.

\section{Tabel 3}

Angket Ahli Materi

Aspek

\section{Indikator}

Kesesuaian isi materi dengan kompetensi inti, kompetensi dasar, tujuan Kelengkapan Komponen Modul

Aspek Kelayakan Isi Kesesuaian sajian dengan tuntutan pembelajaran yang terpusat pada peserta didik

Cara penyajian

\section{Tabel 4}

Angket Ahli Bahasa

\begin{tabular}{ll}
\hline \multicolumn{1}{c}{ Aspek } & \multicolumn{1}{c}{ Indikator } \\
\hline \multirow{2}{*}{ Lugas } & Ketepatan penggunaan istilah \\
& Ketepatan penyusunan kalimat \\
& Keefektifan kalimat \\
& Keefektifan penyusunan paragrap \\
\hline Komunikatif & Pemahaman terhadap pesan atau informasi \\
\hline Dialogis dan interaktif & Kemampuan memotivasi peserta didik \\
\hline Kesesuaian perkembangan & Kemampuan mendorong perkembangan diri peserta didik
\end{tabular}
peserta didik

Kesesuaian dengan kaidah Ketepatan bahasa




\begin{tabular}{lll}
\hline bahasa & Ketepatan ejaan & \\
Tabel 5 & & \\
Angket Ahli Media & & \\
\hline \multicolumn{1}{c}{ Aspek } & Indikator \\
\hline \multirow{3}{*}{ Pembuka } & Dudul (Cover) & \\
& Petar Konsep & \\
& Tujuan (KI dan KD) \\
& Pendahuluan & \\
Bagian Isi & Tujuan (KI dan KD) & \\
& Uraian Materi & \\
& Lembar Kerja & \\
\hline \multirow{2}{*}{ Penutup } & Rangkuman & \\
& Glosarium & \\
\hline
\end{tabular}

Tabel 6

Angket Guru

\begin{tabular}{ll}
\hline \multicolumn{1}{c}{ Aspek } & \multicolumn{1}{c}{ Indikator } \\
\hline & Kemenarikan tampilan modul \\
& Kejelasan tujuan pembelajaran \\
& Kejelasan petunjuk penggunaan modul \\
& Kejelasan uraian materi \\
& Kejelasan bahasa yang digunakan \\
Aspek kelayakan dan aspek & Pemberian kesempatan kepada peserta didik untuk latihan soal secara \\
penggunaan & mandiri \\
& Ketepatan memilih warna background dan warna tulisan \\
& Mendorong rasa ingin tahu peserta didik \\
& Mendorong pengetahuan dan wawasan \\
& Tampilan modul secara keseluruhan \\
\hline
\end{tabular}

Tabel 7

Angket Peserta Didik

\begin{tabular}{ll}
\hline \multicolumn{1}{c}{ Aspek } & \multicolumn{1}{c}{ Indikator } \\
\hline & Kemenarikan tampilan modul \\
& Kejelasan tujuan pembelajaran \\
& Kejelasan petunjuk penggunaan modul \\
& Kejelasan uraian materi \\
Aspek kelayakan dan aspek & Kejelasan bahasa yang digunakan \\
penggunaan & Pemberian kesempatan kepada peserta didik untuk latihan soal secara \\
& mandiri \\
& Ketepatan memilih warna background dan warna tulisan \\
& Mendorong rasa ingin tahu peserta didik \\
& Mendorong pengetahuan dan wawasan \\
& Tampilan modul secara keseluruhan \\
\hline
\end{tabular}

\section{HASIL DAN PEMBAHASAN}

Penelitian pengembangan ini dilakukan di SMA Negeri 1 Jatiagung pada bulan April 2021, adapun responden yang digunakan selama penelitian berjumlah 66 peserta didik kelas X. Modul merupakan salah satu media pembelajaran yang digunakan oleh pendidik sebagai salah satu penunjang dalam kegiatan belajar mengajar. Peserta didik sebagai pembelajar perlu adanya media untuk membantu dalam proses belajar. Modul sendiri merupakan buku yang dibuat dengan tujuan agar peserta didik bisa belajar mandiri dengan atau tanpa bimbingan pendidik (Ana Maulidatul Hasanah, 2019). Pengembangan ADDIE (Analisys, Design, development, Implementation, \& evaluation) (Pudjawan, 2015). 


\section{Analisys}

Pada tahap analisys, peneliti melakukan tahap pengelompokan masalah yang ada di sekolah, yakni pada bagian media pembelajaran. Media yang digunakan belum ditemukan adanya modul sebagai sarana pembelajaran yang bersifat praktik. Kemudian dilanjutkan dengan analisis kebutuhan. Peserta didik memerlukan media yang dapat digunakan secara mandiri yakni dengan membuat modul pembuatan Ecobrick.

Design

Langkah-langkah yang dilalui dalam proses mendesain modul, yakni a) menentukan KI dan $\mathrm{KD}$, b) mengumpulkan materi-materi mengenai pencemaran lingkungan, materi kewirausahaan, Ecopreneurship, dan cara pembuatan Ecobrick, c) menentukan desain cover modul dan desain isi modul, d) menyatukan keseluruhan desain dan materi yang digunakan sehingga menjadi modul yang siap digunakan oleh peserta didik.

\section{Development}

Proses selanjutnya setelah analisis dan desain, yakni proses pengembangan. Pada tahapan ini, modul dikembangkan dan dirancang sesuai dengan desain yang telah dilakukan dan dilakukan tahap validasi kelayakan modul.

Pengembangan modul melalui proses validasi desain atau produk. Validasi dilakukan dengan tiga macam, yaitu validasi desain, validasi isi ahli materi, dan validasi ali bahasa. Berikut ini hasil dari ketiga validasi tersebut.

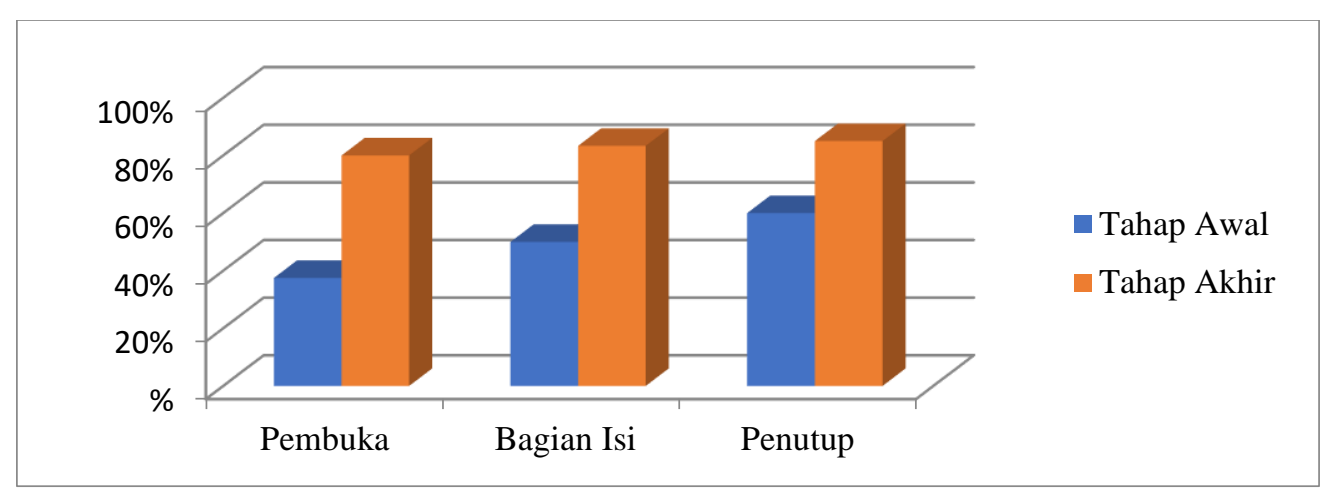

Gambar 1. Validasi Ahli Media

Ahli media: tahap awal validasi diperoleh persentase sebesar $46,875 \%$ dengan kategori cukup layak. Pada tahap akhir diperoleh persentase $82,2 \%$ dengan kategori sangat layak.

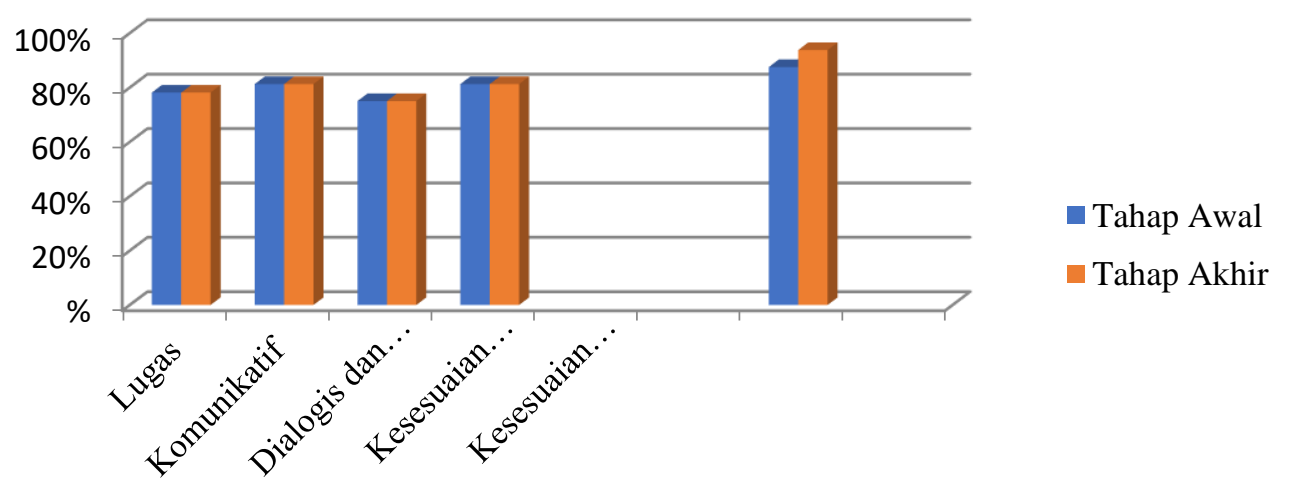

Gambar 2. Validasi Ahli Bahasa

Ahli bahasa: tahap awal validasi diperoleh persentase sebesar 80,68 \% dengan kategori layak. Tahap akhir diperoleh persentase sebesar $81,81 \%$ dengan kategori sangat layak. 


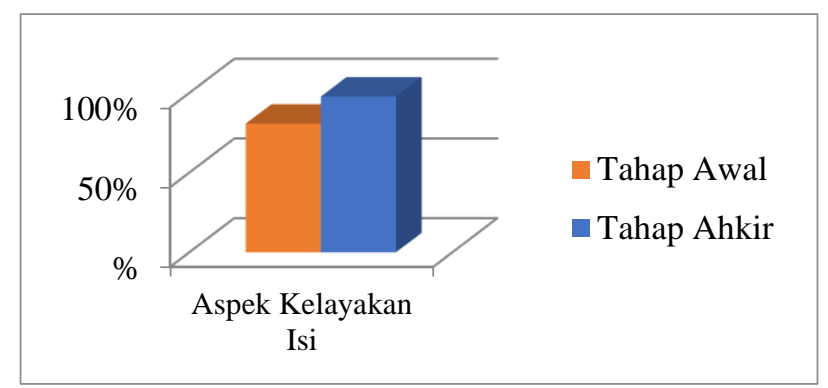

\section{Gambar 3. Validasi Ahli Materi}

Ahli materi: tahap awal diperoleh persentase sebesar 80,68\% dengan kategori layak. Tahap akhir diperoleh persentase 97,72\% dengan kategori sangat layak.

\section{Implementation}

Tahap ini, yakni melakukan implementasi media pembelajaran dalam kegiatan belajar mengajar di sekolah. Uji coba dilakukan kepada peserta didik dan pendidik di sekolah. Adapun hasilnya sebagai berikut:

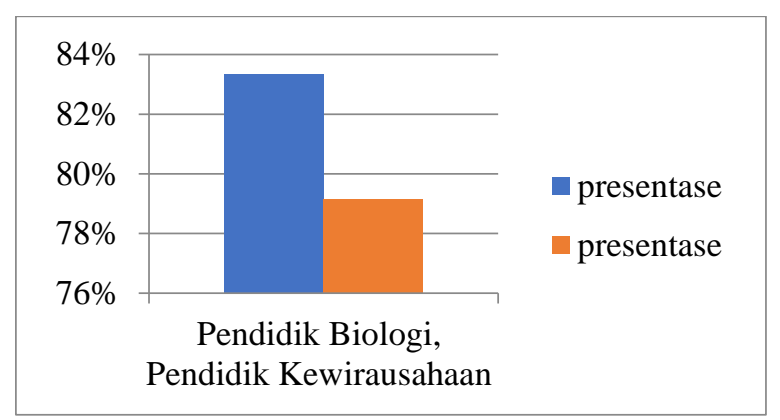

Gambar 4. Penilaian Pendidik

Penilaian yang diberikan pendidik biologi dan pendidik kewirausahaan diperoleh hasil: $83,33 \%$ dengan kriteria sangat layak, dan 79,16\% dengan kriteria layak.

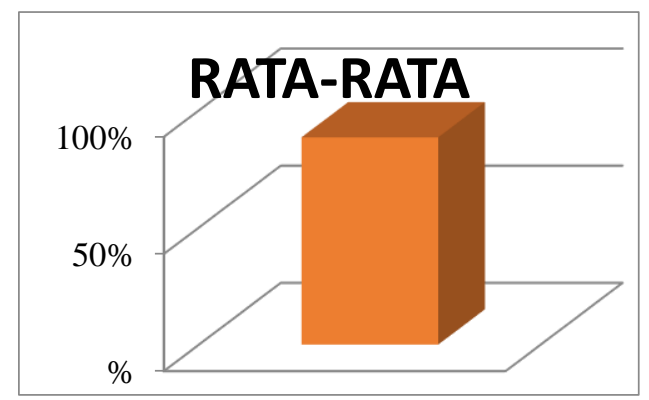

Gambar 5. Hasil Tanggapan Peserta Didik

Berdasarkan hasil tanggapan yang berasal dari peserta diperoleh bahwa modul pembuatan Ecobrick memiliki kriteria sangat layak dengan persentase rata-rata sebesar $88,4 \%$.

\section{Evaluation}

Pada tahapan evaluasi produk dibutuhkan adanya revisi tahap akhir produk yang dikembangkan berdasarkan masukan dan saran siswa yang diberikan selama tahap implementasi. Saran yang diberikan oleh peserta didik, di antaranya adalah modul yang dibuat menarik, namun perlu adanya penambahan gambar-gambar agar pembaca (peserta didik) tidak mengalami 
kebosanan selama proses belajar. Dalam segi bahasa, peserta didik juga menyarankan untuk menggunakan bahasa yang mudah dipahami oleh banyak orang.

Di dalam modul peserta didik dapat menambah pengetahuan dan wawasan tentang materi pencemaran lingkungan terutama yang disebabkan oleh limbah plastik. Selain itu, modul juga menyajikan berbagai jenis plastik dan cara penanganannya. Dengan adanya modul ini, peserta didik diharapkan akan dapat memiliki jiwa Ecopreneurship, yakni memanfaatkan sikap peduli lingkungan dengan mengembangkan berbagai barang yang bermanfaat yang dapat digunakan atau bahkan dapat menghasilkan uang. Jiwa wirausaha akan tertanam dan dibarengi dengan sikap cinta lingkungan.

Pembuatan Ecobrick oleh peserta didik dengan menggunakan modul merupakan salah satu awal bagi tertanamnya sikap cinta terhadap lingkungan. Selain itu, jika terus dikembangkan Ecobrick dapat menjadi sumber penghasilan dalam berwirausaha. Dalam kegiatan pembelajaran, modul dapat menjadi sarana pengembangan diri bagi peserta didik. Peserta didik dapat belajar secara mandiri tanpa bimbingan secara langsung yang dilakukan oleh pendidik. Mengingat pembelajaran yang masih berlangsung secara daring, sehingga modul pembuatan Ecobrick ini dapat teruji secara tepat dalam hal belajar mandiri di rumah masing-masing. Peserta didik melakukan praktik mandiri dengan bantuan modul pada lembar kerja peserta didik dalam hal pembuatan Ecobrick.

\section{KESIMPULAN}

Adapun dari hasil penelitian yang telah dilakukan oleh peneliti adalah 1). Modul pembuatan Ecobrick sebagai sarana pengembangan diri berbasis Ecopreneurship layak digunakan sebagai media pembelajaran. Mengingat pembelajaran yang dilakukan secara online (daring) peserta didik dapat mempraktikkan proses pembuatan Ecobrick yang terdapat pada lembar kerja peserta didik dengan baik secara mandiri di rumah masing-masing. Proses pembuatan juga memanfaatkan sampah plastik yang sudah tidak terpakai. Ini membuktikan bahwasanya modul pembuatan Ecobrick layak untuk digunakan baik dengan atau tanpa bimbingan pendidik, 2). Tanggapan peserta didik dan pendidik terhadap modul pembuatan Ecobrick ini sangat baik dapat dilihat dari hasil penilaian, yakni diperoleh oleh peserta didik sebesar 88,47 \% sehingga dikatakan sangat layak (SL). Hasil penilaian oleh pendidik biologi sebesar 83,33\% sehingga dikatakan sangat layak (SL) untuk digunakan, kemudian hasil penilaian oleh pendidik kewirausahaan diperoleh hasil sebesar 79,16\% sehingga produk dikatakan layak (L).

\section{DAFTAR PUSTAKA}

Adinugraha, F. (2017). Media Pembelajaran Biologi Berbasis Ecopreneurship. Jurnal Formatif, $7(3), 220$.

Afandi, M. I. (2010). Pengembangan Buku Panduan Pengasuhan untuk Mengembangkan Potensi Membaca Anak Usia Prasekolah. Skripsi, 56.

Afriza, Edi Fitriana, et. al. (2018). Edukasi Ecobrik Sebagai Solusi Manajemen Pengelolaan Sampah Berbasis Masyarakat. 2, 799-807.

Ana Maulidatul Hasanah, E. (2019). Pengembangam Modul Biologi Bernilai Islam Materi Sistem Reproduksi Pada Manusia. Bioeduca: Journal Of Biology Education, 1(1), 18-28. Retrieved from http://journal.walisongo.ac.id/index.php/bioeduca.

Anih, E. (2015). Ecopreneurship Education Berbasis Prakarya Dalam Kurikulum 2013. Jurnal Pendidikan Guru Sekolah Dasar, 1(1), 113-121.

Ansali, M. A., \& Dewi, M. (2019). Strategi Komunikasi Pemberdayaan Masyarakat Pesisir PantaiKelompok Swadaya Masyarakat Jiwa Laut. 1(1). 
Asri, S., Bank, G., Warsito, B., Raharjo, M., Santoso, R., Yasin, H. (2018). Pelatihan Pemanfaatan Sampah Plastik Berpotensi Ekonomis bagi Nasabah Bank Sampah Sempulur Asri. 1, 368-373.

Fatimura, M. (2020). Evaluasi Kinerja Reaktor Pirolisis Non Katalis Dalam Mengkonversikan Limbah Plastik Menjadi Bahan Bakar Minyak. Jurnal Ilmiah Teknik Kimia, 4(1), 1-7.

Gunawan, A., Teknik, F., \& Bengkulu, U. (2018). Pengolahan limbah plastik berbasis mitra berkegiatan lingkungan. 1, 77-85.

Hamid, A., \& Alberida, H. (2021). Pentingnya Mengembangkan E-Modul Interaktif Berbasis Flipbook di Sekolah Menengah Atas. Edukatif: Jurnal Ilmu Pendidikan, 3(3), 911-918. https://doi.org/http://edukatif.org/index.php/edukatif/index.

Handoko, A., Sajidan, \& Maridi. (2016). Pengembangan Modul Biologi Berbasis Discovery Learning (Part Of Inquiry Spectrum Learning-Wenning) Pada Materi Bioteknologi Kelas XII IPA di SMA Negeri 1 Magelang Tahun Ajaran 2014-2015. Jurnal Inkuiri, 5(3), 144-154.

Pudjawan, K. (2015). Pengembangan Buku Ajar Model Penelitian Analyze Implement Evaluate Design Develop. Seminar Nasional Riset Inovatif, 208-216.

Purba, I. P. M. hardianto. (2021). Implementasi Undang-Undang Nomor 6 Tahun 2018 Tentang Kekarantinaan Kesehatan di Jawa Timur Menghadapi Pandemi Covid-19. Jurnal Pahlawan, 4(1), 1-11.

Purnama, H., \& Yuriandala, Y. (2010). Studi Pemanfaatan Sampah Plastik Menjadi Produk dan Jasa Kreatif. 2(1), 21-31.

Riduwan. (2014). Dasar-Dasar Statistik. Bandung: Alfabeta.

Salsabila P. E. al. (2021). Teknologi Inovasi Pengolahan Limbah Plastik Menjadi Produk Umkm Guna Menopang Ekonomi Keluarga Dalam Mencerdaskan Keterampilan Masyarakat. Jurnal Pengabdian Masyarakat, 1(1), 1-11.

Sari, R. T., Angreni, S., \& Fortuna, R. A. (2019). Pengembangan Modul Pembelajaran IPA Berbasis Pendekatan Kontruktivisme Untuk Kelas V SD. Bio-Pedagogi: Jurnal Pembelajaran Biologi, 8(2), 89-93.

Suharsimi, A. (2013). Manajemen Pendidikan. Jakarta: PT. Rineka Cipta.

Suryani, A. S. (2020). Dampak Pandemi COVID-19 Terhadap Lingkungan Global. 12(13), 13-18. Retrieved from http://puslit.dpr.go.id

Wulandari, E. (2018). Pengembangan Media Pembelajaran Interaktif Berbasisi E-Book Pada Materi Sistem Pencernaan Untuk SMP Kelas VII. Skripsi, 41. 